\title{
Urgensi Pengaturan Desa dalam Undang-Undang Dasar Negara Republik Indonesia Tahun 1945
}

\author{
Ni'matul Huda* \\ DOI: https://doi.org/10.22304/pjih.v4n1.a1
}

\begin{abstract}
Abstrak
Artikel ini membahas dua topik penting, pertama, apakah Pasal 18B UUD 1945 belum mengakomodir desa di dalamnya? Kedua, apa urgensi pengaturan desa di dalam UUD 1945? Penelitian ini menggunakan pendekatan filosofis dan perundang-undangan. Analisis terhadap bahan hukum dilakukan secara deskriptif kualitatif. Hasil penelitian menyimpulkan bahwa, pertama, Pasal 18B UUD 1945 belum mengakomodir desa di dalamnya, karena yang diatur di dalamnya hanyalah kesatuan masyarakat hukum adat yang berbeda dengan desa. Kedua, urgensi pengaturan desa dimasukkan dalam UUD 1945 untuk memberikan dasar konstitusional yang lebih kuat bagi desa, karena sesungguhnya desa adalah cikal bakal yang membentuk negara. Di samping itu, untuk menjaga agar eksistensi desa tidak berubah-ubah mengikuti langgam politik kekuasaan.
\end{abstract}

Kata kunci: desa, konstitusi, Pasal 18B UUD 1945, masyarakat hukum adat, pemerintahan daerah

\section{The Urgency to Regulate Administrative Village in the 1945 Constitution of Republic of Indonesia}

\begin{abstract}
This article will discuss two important topics, first, to elaborate whether Article $18 B$ of the 1945 Constitution of Republic of Indonesia has regulated administrative village; and second, what is the urgency to regulate administrative village in the 1945 Constitution. This research used philosophical approach and legislative provisions. The analysis on legal materials will be performed in the descriptive and qualitative method. The research concludes that first, Article 18B of the 1945 Constitution has not accommodated administraive village, since it only regulates Adat law communities which is different from administrative village. Second, it is urgent to regulate administrative village in the 1945 Constitution in order to strengthen the constitutional fundamental for administrative village, since historically villages are the basis of the establishment of a state. Furthermore, a constitutional fundamental will ensure that the existence of administrative village will not be abruptly affected by the change in political power.
\end{abstract}

Keywords: village, constitution, Article 18B of the 1945 Constitution, adat law communities, localgovernment

PADJADJARAN Jurnal IImu Hukum Volume 4 Nomor 1 Tahun 2017 [ISSN 2460-1543] [e-ISSN 2442-9325]

* Guru Besar Fakultas Hukum Universitas Islam Indonesia, Jl. Tamansiswa No. 158 Yogyakarta, huda.fh@uii.ac.id, pascahukumuii@yahoo.com, S.H. (UII Yogyakarta), M.Hum. (Universitas Padjadjaran), Dr. (UII Yogyakarta). 


\section{A. Pendahuluan}

Jika dilakukan pembacaan secara cermat hasil perubahan Undang-Undang Dasar 1945 (UUD 1945) yang dilakukan oleh Majelis Permusyawaratan Rakyat (MPR) dalam kurun waktu 1999-2002, tidak ada pembahasan yang spesifik perihal pemerintahan desa. Desa tidak dibahas sebagai entitas tersendiri dari republik ini, tetapi dibahas dalam konteks bagian dari pemerintahan daerah, sebagaimana yang termuat dalam Undang-Undang Nomor 22 Tahun 1999 tentang Pemerintahan Daerah (UU Pemda 1999) dan Undang-Undang Nomor 32 Tahun 2004 tentang Pemerintahan Daerah (UU Pemda 2004). Pembahasan di MPR ketika itu hanya berkaitan dengan pengakuan dan penghormatan terhadap daerah yang berstatus otonomi khusus dan daerah istimewa, serta pengakuan dan penghormatan terhadap masyarakat hukum adat, yang kemudian dituangkan dalam Pasal 18B UUD 1945, yang berbunyi sebagai berikut:

(1) Negara mengakui dan menghormati satuan-satuan pemerintah daerah yang bersifat khusus atau bersifat istimewa yang diatur dengan undang-undang.

(2) Negara mengakui dan menghormati kesatuan-kesatuan masyarakat hukum adat beserta hak-hak tradisionalnya sepanjang masih hidup dan sesuai dengan perkembangan masyarakat dan prinsip Negara Kesatuan Republik Indonesia, yang diatur dengan undang-undang.

Sepertinya ada yang terlupakan atau mungkin memang sengaja tidak dibahas oleh MPR ketika melakukan perubahan UUD 1945 dari tahun 1999-2002, utamanya pada perubahan tahap kedua tahun 2000, ketika dilakukan perubahan terhadap Bab Pemerintahan Daerah pada Pasal 18. Selama pemerintahan Orde Baru struktur pemerintahan terbawah di seluruh Indonesia sudah diseragamkan dengan nama Desa, dan menenggelamkan keragaman pemerintahan terbawah yang sudah mengakar di Indonesia dengan nama Nagari, Marga, Huta, Gampong, dan seterusnya. Padahal desa dan kesatuan masyarakat hukum adat adalah dua entitas yang berbeda.

Ketika berlangsungnya pemerintahan Orde Baru, desa diatur tersendiri dalam Undang-Undang Nomor 5 Tahun 1979 tentang Pemerintahan Desa (UU Pemerintahan Desa) terpisah dari pengaturan pemerintahan daerah (UndangUndang Nomor 5 Tahun 1974 tentang Pemerintahan Di Daerah/UU Pemda 1974), tetapi secara substantif langgam politik hukum yang dipilih dalam mendesain UU Desa 1979 sama persis dengan UU Pemda 1974, yakni sama-sama bercorak sentralistis dan pemusatan kekuasaan di tangan eksekutif. UU Pemda 1979 menyatukan figur kepala desa sekaligus juga ketua Lembaga Permusyawaratan Desa (LMD) dan Sekretaris Desa sekaligus juga Sekretaris LMD.

Pasca reformasi 1998, lahir UU Pemda 1999 yang di dalamnya juga mengatur tentang desa. Artinya pengaturan desa menjadi bagian dari entitas pemerintahan 
daerah. Demikian pula ketika berlakunya UU Pemda 2004, desa sekali lagi juga menjadi bagian dari pemerintahan daerah. Setelah tahun 2014, menjelang hajatan politik pemilihan umum (pemilu) legislatif dan pemilu presiden, pemerintah dan Dewan Perwakilan Rakyat (DPR) menyepakati lahirnya Undang-Undang Nomor 6 Tahun 2014 tentang Desa (UU Desa). Desa diatur tersendiri dan tidak serta merta menjadi bagian dari pemerintahan daerah. Desa dan desa adat dijadikan struktur pemerintahan terbawah dari struktur pemerintahan Indonesia dalam bingkai Negara Kesatuan Republik Indonesia (NKRI).

Melihat fenomena pengaturan desa yang silih berganti seperti diuraikan di atas, maka artikel ini akan beranjak dari keinginan untuk mengusulkan gagasan perlunya dilakukan perubahan kembali UUD 1945, yakni memasukkan pengaturan desa ke dalam UUD 1945. Mengapa desa perlu dimasukkan ke dalam UUD 1945? Apakah Pasal 18B UUD 1945 belum mengakomodirnya?

\section{B. Metode Penelitian}

Penelitian ini merupakan penelitian hukum (normatif). Objek penelitiannya adalah urgensi pengaturan desa di dalam UUD 1945. Penelitian ini mengambil sumber dari bahan hukum primer berupa Risalah Perubahan UUD 1945, UU Pemerintahan Desa, UU Pemda 1999, UU Pemda 2004, dan UU Desa. Di samping itu, juga digunakan bahan hukum sekunder berupa literatur, hasil penelitian terdahulu, dan jurnal yang relevan dengan objek penelitian.

Penelitian ini menggunakan pendekatan filosofis dan perundang-undangan. Pendekatan filosofis digunakan untuk menganalisis permasalahan pertama terkait urgensi pengaturan desa dimasukkan dalam UUD 1945. Adapun pendekatan perundang-undangan digunakan untuk memecahkan permasalahan Pasal 18B UUD 1945 yang menurut peneliti belum mengakomodir desa di dalamnya.

Analisis terhadap bahan hukum dilakukan secara deskriptif kualitatif. Pengolahan data pada hakikatnya merupakan kegiatan untuk mengadakan sistematisasi terhadap bahan-bahan hukum. Sistematisasi berarti membuat klasifikasi terhadap bahan-bahan hukum tersebut untuk memudahkan pekerjaan analisis dan konstruksi. ${ }^{1}$ Data yang sudah disistematisasi kemudian dianalisis secara kualitatif.

\section{Pembahasan dan Analisis}

\section{Teori Perubahan Konstitusi}

Menurut Wheare, ${ }^{2}$ perubahan UUD akibat dorongan kekuatan (forces) yang terjadi dapat berbentuk: pertama, kekuatan-kekuatan yang kemudian melahirkan

Soerjono Soekanto, Pengantar Penelitian Hukum, Jakarta: UI Press, 1986, hlm. 251-252.

K.C. Wheare, Modern Constitutions, London: Oxford University Press, 1975, hlm. 67-136. 
perubahan keadaan (circumstances) tanpa mengakibatkan perubahan bunyi yang tertulis dalam UUD, melainkan terjadi perubahan makna. Suatu ketentuan UUD diberi makna baru tanpa mengubah bunyinya. Kedua, kekuatan-kekuatan yang melahirkan keadaan baru itu mendorong perubahan atas ketentuan UUD, baik melalui perubahan formal (formal amandement), putusan hakim, hukum adat, maupun konvensi.

Ada hal-hal prinsip yang harus diperhatikan dalam perubahan UUD. Menurut Bagir Manan, ${ }^{3}$ perubahan UUD berhubungan dengan perumusan kaidah konstitusi sebagai kaidah hukum negara tertinggi. Dalam hal ini, terlepas dari beberapa kebutuhan mendesak, perlu kehati-hatian, baik mengenai materi muatan maupun cara-cara perumusan. Memang benar, penataan kembali UUD 1945 untuk menjamin pelaksanaan konstitusionalisme dan menampung dinamika baru di bidang politik, ekonomi, sosial, dan lain-lain. Tapi jangan sekali-kali perubahan itu semata-mata dijadikan dasar dan tempat untuk menampung berbagai realitas kekuatan politik yang berbeda dan sedang bersaing dalam MPR.

Sri Soemantri menegaskan dalam mengubah UUD harus ditetapkan dulu alasan dan tujuannya. Jika hal itu sudah disepakati, baru dapat dipikirkan langkah selanjutnya berdasarkan alasan dan tujuan perubahan itu. Misalnya, selama ini UUD terkesan terlalu berorientasi pada eksekutif. Karena itu, ditentukanlah bahwa tujuan dari perubahan UUD adalah untuk membatasi eksekutif. Kemudian apa yang dilakukan untuk membatasi kekuasaan eksekutif? Itu harus dipikirkan masakmasak. Misalnya, kontrol terhadap eksekutif harus diperkuat. Itu berarti kedudukan legislatif mesti diperkuat. Jadi kita harus kembali pada alasan dan tujuan dari perubahan itu. Misalnya tujuannya adalah mewujudkan negara demokrasi, maka kita harus berbicara mengenai sistem pemerintahan. ${ }^{4}$

Perubahan konstitusi dipengaruhi oleh seberapa besar badan yang diberikan otoritas melakukan perubahan memahami tuntutan perubahan dan seberapa jauh kemauan anggota badan itu melakukan perubahan. Perubahan konstitusi tidak hanya bergantung pada norma perubahan, tetapi lebih ditentukan oleh kelompok elite politik yang memegang suara mayoritas di lembaga yang mempunyai kewenangan melakukan perubahan konstitusi. Lembaga yang mempunyai kewenangan melakukan perubahan harus berhasil membaca arah perubahan yang dikehendaki oleh masyarakat yang diatur secara kenegaraan.

Dalam setiap perubahan konstitusi terdapat paradigma perubahan yang harus dipatuhi oleh pembuat perubahan. Paradigma perubahan itu menjadi 'politik hukum' perubahan konstitusi. Kesulitannya perubahan yang diinginkan oleh masyarakat politik tidak senantiasa sama dengan substansi perubahan yang

Bagir Manan, "Perubahan UUD 1945”, Forum Keadilan, No. 30, 31 Oktober 1999, hlm. 45.

Wawancara Sri Soemantri di Forum Keadilan, No. 14, 8 Juli 2001. 
diinginkan oleh anggota lembaga yang mempunyai kewenangan melakukan perubahan konstitusi. ${ }^{5}$ Perubahan konstitusi harus didasarkan pada paradigma perubahan agar perubahan terarah sesuai dengan kebutuhan yang berkembang di masyarakat. Paradigma ini digali dari kelemahan sistem bangunan konstitusi lama, dan dengan argumentasi diciptakan landasan agar dapat menghasilkan sistem yang menjamin stabilitas pemerintahan dan memajukan kesejahteraan rakyat. ${ }^{6}$

Paradigma itu mencakup nilai-nilai dan prinsip-prinsip penting yang mendasar atau jiwa (gheist) perubahan konstitusi. Nilai dan prinsip itu dapat digunakan untuk menyusun telaah kritis terhadap konstitusi lama dan sekaligus menjadi dasar bagi perubahan konstitusi atau penyusunan konstitusi baru. Di samping persoalan paradigma dalam perubahan konstitusi, juga perlu diperhatikan aspek teoritik dalam perubahan konstitusi yang akan mencakup masalah prosedur perubahan, mekanisme yang dilakukan, sistem perubahan yang dianut, dan substansi yang akan diubah. ${ }^{7}$

Setiap konstitusi tertulis lazimnya selalu memuat adanya klausula perubahan di dalam naskahnya, sebab betapa pun selalu disadari akan ketidaksempurnaan hasil pekerjaan manusia termasuk pekerjaan membuat atau menyusun UUD. Selain itu, konstitusi sebagai acuan utama dalam pengaturan kehidupan berbangsa dan bernegara adalah merupakan suatu kontrak sosial yang merefleksikan hubunganhubungan kepentingan dari seluruh komponen bangsa yang sifatnya sangat dinamis, sehingga dengan demikian, konstitusi memerlukan peremajaan secara periodik, karena dinamika lingkungan global akan secara langsung atau tidak langsung menimbulkan pergeseran aspirasi masyarakat. ${ }^{8}$

\section{Pembahasan Pasal 18B ayat (2) Undang-Undang Dasar Tahun 1945}

Di dalam perubahan UUD 1945 tidak ada pembahasan yang spesifik perihal pemerintahan desa. Desa tidak dibahas sebagai entitas tersendiri dari republik ini tetapi dibahas dalam konteks bagian dari pemerintahan daerah, sebagaimana nantinya terlihat dalam UU Pemda 1999 dan UU Pemda 2004. Pembahasan justru muncul berkaitan dengan masyarakat hukum adat, yang kemudian dituangkan dalam Pasal 18B ayat (2) UUD 1945. Hal itu tentu sangat jauh berbeda dengan pembahasan di dalam Badan Penyelidik Usaha Persiapan Kemerdekaan Indonesia (BPUPKI) ketika merumuskan pembagian wilayah Indonesia di dalam UUD 1945.

5 A. Mukthie Fadjar dan Harjono (eds.), Pembaharuan Ketatanegaraan Melalui Perubahan Konstitusi, Malang: In-TRANS, 2004, hlm. 39.

6 Ibid., hlm. 85.

7 A. Mukthie Fadjar, Reformasi Konstitusi Dalam Masa Transisi Paradigmatik, Malang: In-TRANS, 2003, hlm. 64.

8 Radi A Gany, "Amandemen UUD 1945 dari Perspektif Apirasi Masyarakat", Makalah dipresentasikan dalam Forum Rektor Indonesia, Bengkulu, 2002. Lihat dalam A. Mukthie Fadjar, Reformasi Konstitusi..., Op.cit., hlm. 60. 
Pembahasan mengenai desa atau pun pemerintahan desa mengalami reduksi yang luar biasa. Ketika Orde Baru, desa diatur dalam UU Pemerintahan Desa, meskipun pengaturan di dalamnya mereduksi keanekaragaman dan kemudian menyeragamkan entitas desa, marga, gampong, huta dll, ke dalam potret desa di Jawa.

Dalam rapat ke-51 Panitia Ad Hoc (PAH) I Badan Pekerja MPR tertanggal 29 Juli 2000 dengan agenda pandangan akhir fraksi terhadap hasil finalisasi Perubahan Kedua UUD 1945 membahas pemerintahan daerah, Hamdan Zoelva dari Perserikatan Bangsa-Bangsa (PBB) menyampaikan beberapa hal berkaitan dengan pemerintahan daerah, yakni sebagai berikut:

“... Pengakuan negara atas adanya masyarakat hukum adat dan hak ulayat atau hak-hak yang melekat kepadanya. Pengakuan ini mengandung arti bahwa negara melindungi dan menjamin keberadaan masyarakat hukum adat dan hak ulayat atau hak-hak yang melekat kepadanya. Di samping itu, negara juga mengakui keberadaan daerah yang bersifat khusus dan istimewa yang keberadaannya itu selanjutnya diatur dengan UU. Menurut pemahaman kami dengan adanya ketentuan ini bisa saja muncul banyak daerah khusus dan daerah istimewa asalkan daerah itu memang betul-betul terbukti memiliki kekhususan atau keistimewaan berdasarkan pertimbangan historis, budaya, adat dan istiadatnya yang berbeda dengan daerahdaerah yang lain." 9

Pada Rapat Lobi PAH I Komisi A MPR tertanggal 14 Agustus 2000, untuk menambah referensi mengenai pemerintahan daerah dihadirkan pakar hukum tata negara, Prof. Dr. Bagir Manan, untuk menyampaikan pandangannya mengenai pengakuan masyarakat hukum adat. Berbagai pertanyaan yang muncul dalam pembahasan di PAH I tersebut dijawab oleh Bagir Manan, mengenai masyarakat tradisional dan hak-hak tradisional diterangkan sebagai berikut:

"Pertama misalnya masyarakat tradisional atau hak-hak tradisional. Yang kita maksud dengan hak-hak tradisionalnya itu karena tadi malam dan di sana juga ada perdebatan antara bapak-bapak, ya di samping hak ulayat masih ada hak-hak lain, sehingga kita perluweskan jadi hakhak tradisional sehingga hak ulayat, hak adat lainnya, hak numpang karang, hak macam-macam itu kalau ada, itu sehingga kita luweskan ke sana. Mengapa kita batasi sepanjang masih hidup artinya masih merupakan kenyataan sosial dalam masyarakat yang bersangkutan, bukan sesuatu hal hukum itu secara sosiologis sudah tidak ada lagi,

9 Mahkamah Konstitusi (MK), Naskah Komprehensif Perubahan UUD Negara Republik Indonesia Tahun 1945, Buku IV Kekuasaan Pemerintahan Negara Jilid 2, Jakarta: Sekretariat Jenderal dan Kepaniteraan MK, 2008, hlm. 270. 
tetapi hanya mempunyai nilai-nilai historis saja. Itu maksudnya sepanjang itu masih hidup tapi nanti kita akan satu persatu lihat kembali.",10

Lebih lanjut Bagir Manan menjelaskan sebagai berikut:

“...Istilah mengembangkan seperti dikatakan Pak Seto misalnya di dalam negara mengakui, menghormati dan mengembangkan karena kita masih di sini satuan-satuan pemerintah asli satuan pemerintahan khusus atau istimewa yang diatur dengan undang-undang. Dari Pak Taufiq, yang diartikan khusus dan istimewa itu adalah DKI dan Yogyakarta, atau Aceh, sedangkan pengertian penjelasan Pasal 18 itu istimewa. Itu bukan itu, istimewa itu justru pemerintahan asli itu, yaitu adalah desa, marga, nagari tapi kalau di sini mau kita artikan itu tidak soal, tapi cara konseptual di dalam konstitusi kita yang ada pengertian istimewa itu adalah itu yang swapraja, desa, dan sebagainya itu. Terus mengapa mengembangkan jadi tidak sekedar mengakui dan menghormati, ini satu pemikiran antitesis dari politik kolonial antara pemerintahan asli. Sebab pemerintahan kolonial itu memelihara pemerintahan desa tapi tidak mengembangkan dan itu kita jalankan sampai misalnya UU No. 5 Tahun 1979. Itu politik dari pemerintahan asli itu tidak ada prinsip membangunnya, tapi memeliharanya saja, sehingga tidak dalam keadaan baik. Maka itu kita masukkan. Jadi ada kewajiban mengembangkan sehingga terjadi modernisasi pada pemerintahan asli itu, itu yang kita inikan. Betul yang kami maksud asli itu adalah karena kita sulit sekali kalau disebut desa sedangkan di Sumatera ada nagari ada segala macamnya. Maka ada marga yang berbeda sehingga kita pakai asli saja, dengan asli itu terkandung desa asli, kemudian huta, kemudian gampung segala macamnya itu. Itu yang kita maksud dengan asli."11

Setelah melalui berbagai perdebatan panjang di MPR, akhirnya pada Rapat Paripurna ke-9 tertanggal 18 Agustus 2000 yang dipimpin oleh M. Amin Rais, menyetujui Perubahan Kedua UUD 1945, yang salah satu materinya mengenai pemerintahan daerah di dalam Pasal 18 diubah dan ditambah menjadi berbunyi sebagai berikut:

$10 \quad$ Ibid., hlm. 283.

$11 \quad$ Ibid., hlm. 283-284. 


\section{BAB VI \\ PEMERINTAH DAERAH}

Pasal 18B

(1) Negara mengakui dan menghormati satuan-satuan pemerintah daerah yang bersifat khusus atau bersifat istimewa yang diatur dengan undang-undang.

(2) Negara mengakui dan menghormati kesatuan-kesatuan masyarakat hukum adat beserta hak-hak tradisionalnya sepanjang masih hidup dan sesuai dengan perkembangan masyarakat dan prinsip Negara Kesatuan Republik Indonesia, yang diatur dengan undang-undang.

Adapun yang dimaksud dengan masyarakat hukum adat (Pasal 18B ayat (2)) adalah masyarakat hukum (rechtsgemeenschap) yang berdasarkan hukum adat atau adat istiadat seperti desa, marga, nagari, gampong, meusanah, huta, negorij dan lain-lain. Masyarakat hukum adalah kesatuan masyarakat - bersifat teritorial atau genealogis - yang memiliki kekayaan sendiri, memiliki warga yang dapat dibedakan dengan warga masyarakat hukum lain dan dapat bertindak ke dalam atau ke luar sebagai satu kesatuan hukum (subjek hukum) yang mandiri dan memerintah diri mereka sendiri. Kesatuan-kesatuan masyarakat hukum ini tidak hanya diakui tetapi dihormati, artinya mempunyai hak hidup yang sederajat dan sama pentingnya dengan kesatuan pemerintahan lain seperti kabupaten dan kota. ${ }^{12}$

Pengakuan dan penghormatan itu diberikan sepanjang masyarakat hukum dan hak-hak tradisional masih nyata ada dan berfungsi (hidup), dan sesuai dengan prinsip-prinsip negara kesatuan. Pembatasan ini diperlukan untuk mencegah tuntutan seolah-olah suatu masyarakat hukum masih ada sedangkan kenyataan telah sama sekali berubah atau hapus, antara lain karena terserap pada satuan pemerintahan lainnya. Juga harus tunduk pada prinsip negara kesatuan.

Meskipun pengakuan dan penghormatan terhadap kesatuan masyarakat hukum adat beserta hak-hak tradisionalnya ditampung dalam pasal ini (Pasal 18B ayat (2)), namun oleh karena rumusannya diubah atau menghilangkan kalimat intinya "hak-hak asal-usulnya", maka pengakuan dan penghormatan dalam Pasal 18B mengandung makna yang berbeda dengan pengakuan dan penghormatan dalam Pasal 18 sebelum perubahan. ${ }^{13}$ Perubahan tahap IV (2002), seperti ditegaskan dalam Aturan Tambahan Pasal I, tidak lagi mengakui Penjelasan UUD

12 Bagir Manan, Menyongsong Fajar Otonomi Daerah, Yogyakarta: Pusat Studi Hukum Fakultas Hukum UII, 2001, hlm 7-17.

13 Menurut Zen Zanibar tidak ada penjelasan tentang kesamaan makna antara "hak-hak tradisional” dengan “ hak-hak asal-usul". Zen Zanibar MZ, "Otonomi Desa Dengan Acuan Khusus Pada Desa Di Provinsi Sumatera Selatan”, Disertasi, Jakarta: Program Pascasarjana FH UI, 2003, hlm. 389-390. 
1945 sebagai bagian tidak terpisahkan dari UUD 1945. Dengan demikian asas desentralisasi tidak lagi seperti dimaksud perumus UUD 1945. Jiwa utama asas desentralisasi yang meletakkan desentralisasi pada masyarakat hukum adat dengan sendirinya ditinggalkan. ${ }^{14}$

Berkenaan dengan pengakuan dan penghormatan terhadap masyarakat hukum adat, Pasal 18B ayat (2) UUD 1945 menegaskan, "Negara mengakui dan menghormati kesatuan-kesatuan masyarakat hukum adat beserta hak-hak tradisionalnya sepanjang masih hidup dan sesuai dengan perkembangan masyarakat dan prinsip Negara Kesatuan Republik Indonesia, yang diatur dengan undang-undang". Kemudian di dalam Pasal 28I ayat (3) UUD 1945 secara tegas menyatakan bahwa "Identitas budaya dan hak masyarakat tradisional dihormati selaras dengan perkembangan zaman dan peradaban." Hal ini menunjukkan bahwa pengakuan terhadap eksistensi masyarakat hukum adat tidak hanya bersifat sosiologis, tetapi juga diakui keberadaannya sebagai subjek hukum penyandang hak dan kewajiban.

Menurut Jimly Asshiddiqie, ${ }^{15}$ kesatuan masyarakat hukum adat sebagai unit organisasi masyarakat hukum adat itu haruslah dibedakan dari masyarakat hukum adatnya sendiri sebagai isi dari kesatuan organisasinya itu. Kesatuan masyarakat hukum adat itu sendiri dipersyaratkan harus masih hidup. Suatu masyarakat bisa saja masih hidup dalam arti bahwa warganya memang belum mati, tetapi tradisi hukum adatnya sudah tidak lagi dijalankan atau tidak lagi dikenal, baik dalam teori maupun dalam praktik. Dalam suatu komunitas masyarakat dapat pula terjadi bahwa warganya memang orang baru sama sekali atau sebagian terbesar pendatang, sedangkan orang aslinya sudah meninggal atau berpindah ke tempat lain. Tetapi tradisi hukum adatnya, meskipun tidak dipraktikkan lagi, tetap terekam dalam catatan sejarah dan dalam buku-buku pelajaran yang pada suatu hari dapat saja dipraktikkan lagi.

Satjipto Rahardjo berpandangan bahwa ketentuan Pasal 18B ayat (2) tersebut masih ditulis dalam tradisi kemutlakan dan hegemonial serta menunjukkan betapa negara merasa memiliki sekalian kekuasaan (authority) dan kekuatan (power) untuk menentukan apa yang terjadi di Negara Kesatuan Republik Indonesia ini, termasuk apakah hukum adat masih berlaku atau tidak. ${ }^{16}$

"Kehadiran hukum adat tidak memikirkan dan mempertimbangkan apakah ia akan diakui atau tidak oleh kekuasaan negara, melainkan karena ia harus muncul. Kata-kata "harus muncul" menunjukkan otentisitas hukum adat. Pada dasarnya ia muncul dari dalam

$14 \quad$ lbid., hlm. 390.

15 Jimly Asshiddiqie, Menuju Negara Hukum Yang Demokratis, Jakarta: Sekretariat Jenderal dan Kepaniteraan MK, 2008, hlm. 815-816.

16 Satjipto Rahardjo, "Hukum Dalam Jagad Ketertiban", Bahan Bacaan Program Doktor Ilmu Hukum Universitas Diponegoro, Semarang, 2005/2006, hlm. 3. 
kandungan masyarakat sendiri secara otonom dan oleh karena itu disebut otentik..."

Lebih lanjut Satjipto mengatakan Pasal 18B ayat (2) UUD 1945 sudah menjadi hukum positif, sehingga kita terikat kepadanya. Terikat berarti menerima dan dimulai dengan membaca apa isi peraturan tersebut. Membaca peraturan bukanlah mengeja kalimat dan kata-kata dari peraturan, melainkan lebih daripada itu, kita memberi makna terhadap peraturan tersebut, ${ }^{17}$ sebagaimana dapat dipaparkan sebagai berikut:

(1) 'Sepanjang masih hidup'. Persyaratan tersebut perlu diteliti dengan seksama dan hati-hati, tidak hanya menggunakan tolok ukur kuantitatif-rasional, melainkan lebih dengan empati dan partisipasi. Kita tidak semata-mata melakukan pengamatan dari luar, melainkan juga dari dalam, dengan menyelami perasaan masyarakat setempat. Metodologi yang digunakan adalah partisipatif.

(2) 'Sesuai dengan perkembangan masyarakat'. Syarat tersebut tidak ditafsirkan dari segi ekonomi dan politik, melainkan dari kacamata masyarakat setempat. Penafsiran dari kedua segi tersebut mengandung risiko untuk memaksakan (imposing) kepentingan raksasa atas nama 'perkembangan masyarakat'.

(3) 'Sesuai dengan prinsip NKRI'. Negara Republik Indonesia dan masyarakat lokal adalah satu kesatuan tubuh. Keduanya tidak dihadapkan secara dikotomis atau hitam putih. Masyarakat lokal atau adat adalah bagian dari dan darah daging dari NKRI itu sendiri.

(4) 'Diatur dalam undang-undang'. Indonesia adalah negara berdasar hukum. Apabila dalam negara yang demikian itu segala diserahkan kepada hukum, maka kehidupan sehari-hari tidak akan berjalan dengan produktif. Untuk itu, dalam menjalankan hukum sekaligus memberi makna terhadap peraturan yang tertulis hitam putih itu.

Lebih lanjut Satjipto menyarankan agar dalam membaca, memaknai, dan menerapkan Pasal 18B ayat (2) UUD 1945 itu Mahkamah Konstitusi (MK) dan pengadilan-pengadilan lain disemangati oleh keinginan dan tekad untuk menjaga dan merawat hukum adat sebaik-baiknya. ${ }^{18}$

Dari perdebatan yang terjadi di MPR ketika melakukan perubahan terhadap Pasal 18 UUD 1945 nampak tidak ada yang memperdebatkan tentang perlu tidaknya entitas 'desa' diatur di dalam UUD 1945. Semua perdebatan hanya difokuskan pada perlunya pengakuan negara terhadap entitas 'kesatuan masyarakat hukum adat' yang sudah dibuat 'mati suri' oleh kebijakan pemerintah Orde Baru menjadi desa seperti layaknya desa di Jawa melalui UU Pemerintahan Desa.

$17 \quad$ lbid., hlm. 12-13.

18 Ibid., hlm. 13. 


\section{Urgensi Pengaturan Desa dalam UUD NRI Tahun 1945}

Jika dibaca secara mendalam makna pengaturan dalam Pasal 18 UUD 1945 (sebelum perubahan) berikut Penjelasannya, dapat dikatakan bahwa esensi dari Pasal 18 UUD 1945 adalah adanya pengakuan negara terhadap apa yang disebut dengan 'otonomi desa' dewasa ini. Lebih dari itu, dengan menyebutkan desa sebagai susunan asli yang memiliki hak asal-usul, menurut UUD 1945, hanya desa yang dipastikan memiliki otonomi. Adapun 'daerah-daerah besar dan kecil lainnya', semacam provinsi, kabupaten, atau kecamatan yang dikenal dalam sistem pemerintahan nasional sekarang ini, dapat saja bersifat otonom atau administratif belaka. Apakah tiap-tiap daerah besar dan kecil itu diberi status otonomi atau administratif tergantung pada 'kebutuhan', perimbangan kekuatan politik pusat dan daerah, sebagaimana dituangkan di dalam undang-undang. ${ }^{19}$

Selain itu, dengan menyebut desa sebagai susunan asli, desa adalah 'persekutuan sosial, ekonomi, politik, dan budaya' yang berbeda hakikatnya dengan sebuah persekutuan administratif sebagaimana yang dimaksudkan dengan 'pemerintahan desa' dalam berbagai peraturan perundang-undangan yang ada. Karena itu, sebagai susunan asli, kerapkali desa mewujudkan diri sebagai apa yang disebut Ter Haar sebagai dorps republik atau 'negara kecil', sebagai lawan kata 'negara besar' yang mengacu pada suatu tatanan modern state. ${ }^{20}$

Berkaitan dengan adanya pengakuan atas otonomi desa ini, dalam wacana politik hukum dikenal adanya 2 (dua) macam konsep hak berdasarkan asal usulnya. Setiap hak berbeda satu dengan lainnya. Pertama, hak yang bersifat berian (hak berian) dan kedua, hak yang merupakan bawaan yang melekat pada sejarah asalusul unit yang memiliki otonomi itu (hak bawaan). Dengan menggunakan 2 (dua) pembedaan ini, digolongkan bahwa otonomi daerah yang dibicarakan banyak orang dewasa ini adalah otonomi yang bersifat berian. Karena itu, wacananya bergeser dari hak menjadi wewenang (authority). Kewenangan selalu merupakan pemberian, sehingga selalu harus dipertanggungjawabkan. Selain itu, konsep urusan rumah tangga daerah hilang diganti dengan konsep kepentingan masyarakat. Dengan demikian, otonomi daerah merupakan kewenangan pemerintahan daerah untuk mengatur kepentingan masyarakat di daerah. ${ }^{21}$

Berbeda dengan hak yang bersifat berian, hak bawaan adalah hak yang telah tumbuh berkembang dan terpelihara oleh suatu kelembagaan (institution) yang mengurus urusan rumah tangganya sendiri. Dalam UUD 1945, konsep hak yang bersifat bawaan inilah yang melekat pada 'daerah yang bersifat istimewa' yang

19 R Yando Zakaria, "Pemulihan Kehidupan Desa dan UU No. 22 Tahun1999”, dalam buku Desentralisasi, Globalisasi, dan Demokrasi Lokal, yang disusun oleh Jamil Gunawan (et.al) (eds.), Jakarta: LP3ES, 2005, hlm. 336.

$20 \quad$ Ibid., hlm. 337.

21 Ibid. 
memiliki 'hak-hak asal usul'. Karena itu, berbeda dengan pemerintah daerah, desa dengan otonomi desa, yang muncul sebagai akibat hak asal usul dan karenanya bersifat istimewa itu, memiliki hak bawaan. ${ }^{22}$ Hak bawaan desa sebagai susunan asli itu setidaknya mencakup hak atas wilayah, yang kemudian disebut sebagai wilayah hak ulayat, sistem pengorganisasian sosial yang ada di wilayah yang bersangkutan (sistem kepemimpinan termasuk di dalamnya), aturan dan mekanisme pembuatan aturan di wilayah yang bersangkutan, yang mengatur seluruh warga (asli atau pendatang) yang tercakup di wilayah desa yang bersangkutan.

Sejatinya inilah pangkal dari ketegangan yang nyaris abadi antara negara di satu pihak dan masyarakat (komunitas dan/atau desa) di pihak lain. Ketegangan itu menyangkut hal bagaimana negara merealisasikan otonomi desa yang secara politis dan hukum terakomodasi dalam peraturan perundang-undangan yang ada, khususnya yang menyangkut hak atas penguasaan atas wilayah desa, aturanaturan, dan sistem pengorganisasian hidup bersama di wilayah itu. ${ }^{23}$

Menurut Attamimi, teori bernegara bangsa Indonesia yang berdasar Cita Negara Indonesia sebagaimana tercermin dalam sistem pemerintahan 'Republik Desa', diwujudkan oleh para penyusun UUD 1945 ke dalam sistem Pemerintahan Negara Indonesia yang modern. Jauh sebelum Indonesia merdeka, Tan Malaka (1924), Bung Karno (1932), dan Bung Hatta (1932) menghendaki bentuk Negara Republik, yang telah ada dalam wujud nagari dan desa. Dengan mengalihkan dasardasar sistem pemerintahan Negara Republik Indonesia dan dengan disertai asasasas negara modern, yaitu wawasan negara berdasar atas hukum (rechtstaat) dan wawasan pemerintahan berdasar sistem konstitusi (constitutionele system), Negara Republik Indonesia benar-benar mempunyai sistem sendiri dan merupakan negara yang mempertahankan ciri khasnya yang asli namun menyempurnakannya dengan unsur-unsur negara modern. ${ }^{24}$

Sebagaimana yang dinyatakan oleh Usep Ranawidjaja, bahwa salah satu sumber hukum tata negara Indonesia adalah hukum tata negara adat, yaitu hukum yang tumbuh dan berkembang di dalam kehidupan sehari-hari dari rakyat yang diakui berlakunya oleh penguasa, baik yang berasal dari zaman dahulu (masa penjajahan dan sebelumnya) maupun yang timbul dan berkembang di dalam masa kemerdekaan. Misalnya dari hukum tata negara adat yang berasal dari zaman dahulu adalah ketentuan-ketentuan hukum mengenai swapraja (kedudukannya, struktur pemerintahannya, organisasi jabatan-jabatan yang ada didalamnya dsb), mengenai persekutuan hukum kenegaraan asli lainnya (desa kuria, gampong dsb),

22 Ibid.

23 Ibid., hlm. 338.

24 A. Hamid S. Attamimi, "Peranan Keputusan Presiden RI dalam Penyelenggaraan Pemerintahan Negara", Disertasi, Jakarta: Universitas Indonesia, 1990, hlm. 103-104. 
mengenai peradilan agama. Contoh hukum tata negara adat yang timbul di masa kemerdekaan adalah ketentuan-ketentuan hukum mengenai pengaturan swapraja yang de facto tidak diakui adanya oleh penguasa (swapraja Surakarta, swaprajaswapraja di Sumatera), ketentuan-ketentuan hukum mengenai persekutuanpersekutuan hukum kenegaraan asli (desa dsb) di dalam kota-kota besar yang kehidupannya tidak sesuai lagi dengan kaidah-kaidah Inlandse Gemeente Ordonantie atau hukum adat dahulu (umpamanya tentang hak ulayat, pemilihan dan penetapan penjabat-pejabatnya, penggabungan satu sama lain). ${ }^{25}$

Bagaimana hubungan otonomi daerah dengan otonomi desa dalam konsep NKRI? Dalam pandangan Sutoro Eko, ${ }^{26}$ sejauh ini belum ada definisi formal tentang otonomi desa yang dirumuskan dalam undang-undang. Namun dalam wacana yang berkembang ada empat cara pandang dan pemahaman tentang otonomi desa. Pertama, cara pandang legal formal yang sering dikemukakan oleh para ahli hukum. Dalam UU sering ditemukan diktum "desa adalah kesatuan masyarakat hukum yang mengatur dan mengurus rumah tangganya sendiri" sebagai definisi standar otonomi desa. Pengertian ini berarti desa merupakan sebuah subjek hukum yang berhak dan berwenang membuat tindakan hukum: membuat peraturan yang mengikat, menguasai tanah, membuat surat-surat resmi, berhubungan dengan pengadilan, menyelenggaraan kerjasama, dan lain-lain. Padahal otonomi tidak hanya sekedar persoalan hubungan hukum, tetapi hubungan antara desa dengan negara. Desa baru bisa disebut otonom kalau ia memperoleh pembagian kewenangan dan keuangan dari negara, sehingga desa mempunyai kewenangan untuk mengelola pemerintahan.

Kedua, otonomi desa baru dipahami dan ditegaskan sebagai bentuk pengakuan negara terhadap eksistensi desa beserta hak asal-usul dan adat istiadatnya. Ini artinya negara tidak merusak, melainkan melindungi eksistensi desa. Negara juga harus memberikan pengakuan terhadap eksistensi desa yang umurnya jauh lebih tua ketimbang NKRI. Pengakuan adalah pijakan pertama, tetapi pengakuan belum cukup. Lebih dari sekedar pengakuan, otonomi desa berarti pembagian kekuasaan, kewenangan dan keuangan kepada desa.

Ketiga, konsep 'self-governing community' sering juga dirujuk sebagai padanan frasa 'kesatuan masyarakat hokum', tetapi sejauh ini belum ada elaborasi yang memadai tentang konsep asing itu. Keempat, cara pandang romantik-lokalistik. Meski UU tidak ada rumusan tentang otonomi desa, tetapi wacana resmi

25 Usep Ranawidjaja, Himpunan Kuliah Hukum Tatanegara Indonesia, Jilid I, Bandung: Pustaka Star, 1960, hlm. 15.

26 Sutoro Eko, "Masa Lalu Masa Kini dan Masa Depan Otonomi Desa", dalam buku Pasang Surut Otonomi Daerah, Sketsa Perjalanan 100 Tahun, yang disusun oleh Soetandyo Wignosubroto (et.al), Jakarta: Institute for Local Development dan Yayasan Tifa, 2005, hlm. 527-529. 
menegaskan bahwa desa memiliki 'otonomi asli' berdasarkan asal-usul dan adat setempat. Konsep otonomi asli justru bisa menjadi jebakan yang mematikan bagi desa, sebab banyak hal yang 'asli' milik desa (terutama sumber daya alam) sudah diambil oleh negara dan dieksploitasi oleh investor. ${ }^{27}$

Dalam pandangan Ateng Syafrudin dan Suprin Na'a, konsekuensi dari konsep atau gagasan hukum NKRI bukan saja hanya desentralisasi kewenangan kepada daerah otonom yang melahirkan otonomi daerah, melainkan lebih dari itu yakni pengakuan - ataupun perlindungan terhadap - adanya otonomi desa sebagai otonomi asli bangsa Indonesia sejak sebelum datangnya kolonial Belanda. Pengakuan dimaksud bukan hanya di atas kertas saja seperti kebebasan memberikan nama desa dan sebagainya, tetapi juga harus memberikan implementasi pengakuan terhadap kewenangan-kewenangan desa, terutama kewenangan asli (oroginair) yang telah turun temurun diketahui sebagai kewenangan desa. Dalam hal ini yang harus dijadikan patokan adalah pengakuan atas 'keanekaragaman' sebagai dasar pemikiran dalam desain otonomi desa. ${ }^{28}$

Otonomi desa harus menjadi inti dari konsep NKRI. Dengan catatan bahwa 'otonomi desa' bukan merupakan cabang dari otonomi daerah, karena yang memberi inspirasi adanya otonomi daerah yang khas bagi NKRI adalah otonomi desa. Otonomi desa harus menjadi pijakan dalam pembagian struktur ketatanegaraan Indonesia mulai dari pusat sampai ke daerah yang kemudian bermuara pada regulasi otonomi desa yang tetap berpedoman pada keaslian 'desa' sebagai kesatuan masyarakat hukum. ${ }^{29}$ Perlindungan konstitusi terhadap otonomi desa, secara implisit juga diatur dalam Pasal 28 I UUD 1945, yang menegaskan bahwa "Identitas budaya dan hak masyarakat tradisional dihormati selaras dengan perkembangan zaman dan peradaban".

Pengertian tentang kewenangan sesuatu daerah hukum yang dilukiskan dengan istilah asing 'otonomi' - dalam bahasa Indonesia, hak untuk mengatur dan mengurus 'rumah tangga' sendiri - menurut Soetardjo Kartohadikoesoemo dalam hukum adat sebenarnya tidak dikenal oleh bangsa Indonesia. Pengertian tentang otonomi desa itu adalah ciptaan bangsa Belanda, waktu mereka masih memegang kekuasaan di Indonesia. ${ }^{30}$ Dalam pengertian otonomi menurut tradisi hukum tata negara asing itu, maka desa di Indonesia sebagai daerah hukum yang paling tua menjalankan otonomi sangat luas, lebih luas dari otonomi daerah-daerah hukum di atasnya yang menyusul di kemudian hari, baik yang dibentuk oleh desa-desa bersama-sama dengan sukarela, maupun yang dipaksakan oleh pihak-pihak yang

\footnotetext{
27 Ibid.

28 Ateng Syafrudin dan Suprin Na'a, Republik Desa, Bandung: Alumni, 2010, hlm. 10-11.

29 Ibid., hlm. 11.

30 Soetardjo Kartohadikoesoemo, Desa, Cetakan Pertama, Jakarta: PN Balai Pustaka, 1984, hlm. 281.
} 
lebih kuat. Oleh daerah-daerah hukum yang lebih tinggi itu kemudian otonomi desa mendapat pembatasan-pembatasan tertentu. ${ }^{31}$

Apabila dibaca dalam konsideran menimbang UU Desa secara jelas dinyatakan bahwa desa memiliki hak asal usul dan hak tradisional dalam mengatur dan mengurus kepentingan masyarakat setempat dan berperan mewujudkan cita-cita kemerdekaan berdasarkan UUD 1945. Di samping itu, dalam perjalanan ketatanegaraan Republik Indonesia, desa telah berkembang dalam berbagai bentuk sehingga perlu dilindungi dan diberdayakan agar menjadi kuat, maju, mandiri, dan demokratis sehingga dapat menciptakan landasan yang kuat dalam melaksanakan pemerintahan dan pembangunan menuju masyarakat yang adil, makmur, dan sejahtera.

Di dalam Ketentuan Umum Pasal 1 UU Desa disebutkan "Desa adalah desa dan desa adat atau yang disebut dengan nama lain, selanjutnya disebut Desa, adalah kesatuan masyarakat hukum...". Dari penegasan di atas dapat diketahui di satu sisi pemerintah membedakan entitas desa dengan desa adat, tetapi di sisi yang lain, pemerintah juga menyamakan penyebutan desa dengan desa adat dengan sebutan Desa. Ketentuan tersebut dipertegas kembali di dalam Pasal 6 tentang jenis desa yang membedakan antara Desa dengan Desa Adat. Penyebutan Desa atau Desa Adat sebagaimana dimaksud pada ayat (1) disesuaikan dengan penyebutan yang berlaku di daerah setempat. UU Desa menyebut Desa dan Desa Adat sebagai kesatuan masyarakat hukum, bukan kesatuan masyarakat hukum adat. Demikian pula jika dibaca dalam Penjelasan Umum UU Desa Nomor 4 tentang Desa dan Desa Adat, secara tegas dinyatakan bahwa:

"Desa mempunyai karakteristik yang berlaku umum untuk seluruh Indonesia, sedangkan Desa Adat mempunyai karakteristik yang berbeda dengan Desa pada umumnya, terutama karena kuatnya pengaruh adat terhadap sistem pemerintahan lokal, pengelolaan sumber daya lokal, dan kehidupan sosial budaya masyarakat Desa. Desa Adat pada prinsipnya merupakan warisan organisasi kepemerintahan masyarakat lokal yang dipelihara secara turun temurun yang tetap diakui dan diperjuangkan oleh pemimpin dan masyarakat Desa Adat agar dapat berfungsi mengembangkan kesejahteraan dan identitas sosial budaya lokal. Desa Adat memiliki hak asal usul yang lebih dominan daripada hak asal usul Desa sejak Desa Adat itu lahir sebagai komunitas asli yang ada di tengah masyarakat."

31 Ibid., hlm. 282. 
Hal ini berbeda dengan apa yang ditentukan dalam Pasal 18B ayat (2) UUD 1945 yang berbunyi: "Negara mengakui dan menghormati kesatuan-kesatuan masyarakat hukum adat beserta hak-hak tradisionalnya sepanjang masih hidup dan sesuai dengan perkembangan masyarakat dan prinsip Negara Kesatuan Republik Indonesia, yang diatur dengan undang-undang". Dari penegasan Pasal 18B ayat (2) UUD 1945 tersebut secara jelas dapat diketahui bahwa desa tidak termasuk dalam pengertian kesatuan masyarakat hukum adat. Untuk itu, penulis mengusulkan agar entitas Desa dimasukkan ke dalam UUD 1945, misalnya seperti yang telah ditentukan dalam Pasal 2 ayat (1) Undang-Undang Nomor 23 Tahun 2014 tentang Pemerintahan Daerah, yang menyatakan bahwa: "Negara Kesatuan RI dibagi atas Daerah provinsi dan Daerah provinsi itu dibagi atas daerah kabupaten dan kota. Dalam ayat (2) ditentukan Daerah kabupaten/kota dibagi atas Kecamatan dan Kecamatan dibagi atas kelurahan dan/atau Desa." Dengan demikian usulan yang diajukan adalah perubahan ulang ketentuan Pasal 18 UUD 1945 dengan menambahkan satu ayat pada Pasal 18, yakni ayat (2) berbunyi: "Daerah kabupaten/kota dibagi atas Kecamatan dan Kecamatan dibagi atas kelurahan dan/atau Desa". Sebagai konsekuensi perubahan tersebut maka ayat (2) yang lama berubah menjadi ayat (3) dan seterusnya.

Urgensi pengaturan desa di dalam UUD 1945 untuk memberikan sandaran konstitusional terhadap desa agar eksistensi desa lebih kuat dan tidak sangat bergantung dari langgam politik sesaat seperti yang selama ini sudah terlihat secara jelas, bahkan setelah reformasi dan perubahan UUD 1945 sekalipun, eksistensi desa sangat ditentukan oleh kepentingan politik kekuasaan. Sebagaimana diketahui, ketika berlakunya UU Pemda 1999 jo. UU Pemda 2004, desa menjadi bagian dari pemerintahan daerah, sehingga perhatian pemerintah terhadap desa hanyalah sekedar sepantasnya atau belum menjadi skala prioritas dalam pembangunan daerah.

\section{Penutup}

\section{Kesimpulan}

Setelah melakukan kajian terhadap dua permasalahan yang diteliti, dapat disimpulkan sebagai berikut. Pertama, urgensi pengaturan desa dimasukkan dalam UUD 1945 adalah untuk memberikan dasar konstitusional yang lebih kuat bagi desa, karena sesungguhnya desa adalah cikal bakal yang membentuk negara. Di samping itu, untuk menjaga agar eksistensi desa tidak berubah-ubah mengikuti langgam politik kekuasaan. Kedua, Pasal 18B UUD 1945 belum mengakomodir desa di dalamnya, karena yang diatur di dalamnya hanyalah kesatuan masyarakat hukum adat, yang berbeda dengan desa. Sementara itu, UU Desa membedakan antara Desa dengan Desa Adat berikut pengaturan masing-masing. 


\section{Saran}

Melalui tulisan ini disarankan, pertama, eksistensi desa perlu dikuatkan di dalam UUD 1945 agar memperoleh sandaran yuridis yang lebih kuat, sehingga tidak mudah untuk diubah-ubah sesuai kepentingan politik sesaat. Kedua, perlu dilakukan perubahan ulang terhadap ketentuan Pasal 18 UUD 1945 dengan menambahkan satu ayat pada Pasal 18, yakni ayat (2) berbunyi “Daerah kabupaten/kota dibagi atas Kecamatan dan Kecamatan dibagi atas kelurahan dan/atau Desa". Sebagai konsekuensi perubahan tersebut maka ayat (2) yang lama berubah menjadi ayat (3) dan seterusnya. Ketiga, pengaturan desa harus dipisahkan dari pengaturan pemerintahan daerah agar batas kewenangan yang dimiliki desa menjadi lebih tegas.

\section{Daftar Pustaka}

\section{Buku}

A. Mukthie Fadjar, Reformasi Konstitusi Dalam Masa Transisi Paradigmatik, InTRANS, Malang, 2003.

A. Mukthie Fadjar dan Harjono (eds.), Pembaharuan Ketatanegaraan Melalui Perubahan Konstitusi, In-TRANS, Malang, 2004.

Ateng Syafrudin dan Suprin Na'a, Republik Desa, Alumni, Bandung, 2010.

Bagir Manan, Menyongsong Fajar Otonomi Daerah, Cetakan Kedua, FH UII Press, Yogyakarta, 1999.

Jamin Gunawan (et.al) (eds.), Desentralisasi, Globalisasi, dan Demokrasi Lokal, LP3ES, Jakarta, 2005.

Jimly Asshiddiqie, Menuju Negara Hukum Yang Demokratis, Sekretariat Jenderal dan Kepaniteraan Mahkamah Konstitusi, Jakarta, 2008

Mahkamah Konstitusi, Naskah Komprehensif Perubahan UUD Negara Republik Indonesia Tahun 1945, Buku IV Kekuasaan Pemerintahan Negara Jilid 2, Sekretariat Jenderal dan Kepaniteraan Mahkamah Konstitusi, Jakarta, 2008.

Soerjono Soekanto, Pengantar Penelitian Hukum, UI Press, Jakarta, 1986.

Soetandyo Wignosubroto (et.al), Pasang Surut Otonomi Daerah, Sketsa Perjalanan 100 Tahun, Institute for Local Development dan Yayasan Tifa, Jakarta, 2005.

Soetardjo Kartohadikoesoemo, Desa, Cetakan Pertama, PN Balai Pustaka, Jakarta, 1984.

Usep Ranawidjaja, Himpunan Kuliah Hukum Tatanegara Indonesia, Jilid I, Pustaka Star, Bandung, 1960.

Wheare, K.C., Modern Constitutions, London, Oxford University Press, 1975. 


\section{Dokumen Lain}

A. Hamid S. Attamimi, "Peranan Keputusan Presiden RI dalam Penyelenggaraan Pemerintahan Negara", Disertasi, Universitas Indonesia, Jakarta, 1990.

Bagir Manan, “Perubahan UUD 1945”, Forum Keadilan, No. 30, 31 Oktober 1999.

Satjipto Rahardjo, "Hukum Dalam Jagad Ketertiban", Bahan Bacaan Program Doktor Ilmu Hukum Universitas Diponegoro, Semarang, 2005/2006.

Zen Zanibar MZ, “Otonomi Desa Dengan Acuan Khusus Pada Desa Di Provinsi

Sumatera Selatan", Disertasi, Program Pascasarjana FH UI, Jakarta, 2003.

Wawancara Sri Soemantri, Forum Keadilan, No. 14, 8 Juli 2001.

\section{Dokumen Hukum}

Undang-Undang Dasar Negara Republik Indonesia Tahun 1945.

Undang-Undang Nomor 5 Tahun 1979 Tentang Pemerintahan Desa.

Undang-Undang Nomor 22 Tahun 1999 Tentang Pemerintahan Daerah.

Undang-Undang Nomor 32 Tahun 2004 Tentang Pemerintahan Daerah.

Undang-Undang Nomor 6 Tahun 2014 Tentang Pemerintahan Desa. 